\title{
The eighth plenary of the Intergovernmental Science-Policy Platform for Biodiversity and Ecosystem Services (IPBES-8): online, nexus, and transformative change
}

\author{
Dirk S. Schmeller ${ }^{1} \cdot$ Peter Bridgewater ${ }^{2,3}$
}

Received: 5 July 2021 / Revised: 12 July 2021 / Accepted: 12 July 2021 /

Published online: 27 July 2021

(C) The Author(s), under exclusive licence to Springer Nature B.V. 2021

\begin{abstract}
The Intergovernmental Science-Policy Platform for Biodiversity and Ecosystem Services held its 8th plenary session online in June 2021, during which a new budget was approved up to 2023, continuing work plans were agreed, and scoping documents for two new assessments, the nexus and transformative change assessments, were accepted.
\end{abstract}

Keywords Science-Policy · Global Assessment · Stakeholders · Nature conservation, · Nexus assessment, · Transformative Change

\section{Introduction}

Many researchers around the world study the effects of climate change, biodiversity change and the links of those changes with the functioning of the biosphere. Two UN processes, the Intergovernmental Panel for Climate Change (IPCC) and the Intergovernmental Science-Policy Platform for Biodiversity and Ecosystem Services (IPBES), summarize the scientific knowledge on climate change and biodiversity change in comprehensive and unique assessments, with considerable voluntary efforts from technical and policy experts. Since foundation in 1988, IPCC has had a positive, while slow, awareness raising activity on climate change and its associated challenges, with reports and assessments widely available to the general public. Founded in 2012, IPBES is not yet at the same level of outreach, despite producing major global and regional assessments, including an Assessment Report on Pollinators, Pollination and Food Production (2016), four regional assessments on

Communicated by David Hawksworth.

Dirk S. Schmeller

ds@die-schmellers.de

1 EcoLab, Université de Toulouse, UPS, INPT, Toulouse, France

2 Advanced Wellbeing Research Centre, Olympic Legacy Park, Sheffield Hallam University, Sheffield S9 3TU, UK

3 Institute for Applied Ecology and Institute for Governance and Policy Analysis, University of Canberra, Bruce, ACT 2617, Australia 
Biodiversity and Ecosystem Services and an assessment on land degradation (IPBES 2018), and a Global Assessment on Biodiversity and Ecosystem Services (IPBES 2019). These assessments, as we have discussed previously (Bridgewater 2017; Bridgewater et al. 2019; Schmeller and Bridgewater 2016; Schmeller et al. 2017), are adopted by a full plenary of the IPBES members governments, who also approve a Summary for Policy Makers written in a plainer and clearer style, directed to a non-expert audience.

The Covid-19 pandemic meant IPBES-8 was held online, and after a year (2020) in which there was no IPBES plenary meeting. The chosen video-conferencing system worked generally well and technical glitches were minor. However, global teleconferencing events also come with the disadvantage that each participant remains in their time zone, and this caused those at the furthest east and west from central Europe to request better consideration for any future global online events. Time may also be saved by avoiding welcoming statements and similar during online events, as they are not essential for advancing the work ahead.

Future online plenary sessions may also profit from a modus operandi that avoids observers being largely left aside, as the biggest drawback of the IPBES- 8 format was the ability of observers to participate in anything other than a highly passive fashion. There was much effort made in organising two IPBES-8 stakeholder days prior to the plenary. There was generally a positive feedback given on this event. However, during the plenary, observers could do nothing but observe; observe quietly in front of their computer screens, exchanging a few words via the chat option with colleagues they were able to find in the long list of observers on their frustration on the progress being made, and attempting to write a short message to a country delegate in the hope that it gets read. It was impossible for observers to have briefing events, direct contact and one-on-one discussions with members of delegations, and to participate more actively. This was even true for authors of the scoping documents for the assessments, who only were given an observer role in this version of a plenary. Hence, an important and special part of IPBES, the stakeholder involvement (see also document IPBES/8/INF/16), lacked effective delivery. Developing a more strategic and collaborative approach to stakeholders, a point of criticism in 2019 (Stevance et al. 2020), continues to need more attention.

\section{Meeting mechanics}

The assessments produced thus far by IPBES all carry the same grave messages: that the biosphere is under heavy anthropic pressure and that strong and effective actions are required to reset people's relations with the rest of nature. While the set of IPBES outputs is considerable, the outcomes from those outputs, and the track to impact remains unclear. As an example, the Executive Secretary pointed out the Global Assessment of Biodiversity and Ecosystem Services, adopted by IPBES-7, had been extremely well received around the world. It had been the subject of more than 30,000 online articles, published in 160 countries and 50 languages. Impressive though that is, it does not demonstrate impact, or even outcome except at a superficial level. The Executive Secretary further pointed out that the Global Assessment had influenced a wide range of decision makers and influencers, including Governments and the business sector, and audiences new to biodiversity, such as young people, city councils, activists, actors and artists-yet these are not audiences new to biodiversity, and the actual outcomes are less visible, despite the secretariat tracking more than 200 examples of the impact of the Global Assessment. It is not clear exactly 
what outcomes are being achieved, and how far along the road to impact IPBES has yet travelled.

Budget negotiations were successful by confirming a 2-year budget (2021 and 2022, with a provisional one for 2023), although this had lacklustre support from some of the countries making the most significant contributions. It was encouraging to see some support coming from the private sector (specifically Laboratoires de Biologie Végétale Yves Rocher SA, Kering SA and H \& M Hennes and Mauritz Gbc AB), but there is clearly a long way to go, and limitations on how private sector organisations, including major charitable foundations and benefactors, are able to interact with the Platform may be a disincentive for more activity. In the budget context, the secretariat estimates experts who continue to volunteer their time and efforts to IPBES, remain a significant asset, e.g., their contributions in-kind over 2019 and 2020 had been worth US \$ 5-10 million. These inkind contributions may, however, not be sustainable over long periods of time.

Finally, a workplan for the Bureau, Multidisciplinary Expert Panel (MEP) and their supporting taskforces was agreed, continuing work in capacity building, assessing knowledge, strengthening the knowledge foundation, and supporting policy.

\section{New assessments}

The plenary also discussed two reports on biodiversity and pandemics and biodiversity and climate change that had been arranged and delivered intersessionally- the latter jointly with IPCC. Interestingly, these were not universally accepted, needing a last-minute "friends of the chair" Zoom group to sort out appropriate wording. The problem was about who had authority, suggesting the Secretariat, Bureau, and MEP should have been more transparent and diligent in interacting with platform member states. The adopted decision acknowledged the work of the experts, but was less effusive than the draft decision. Nonetheless, these reports will be a useful resource for the major result of the plenary-approving the launch of two new assessments using the scoping documents which outline the direction of work for the assessments. These two additional assessments follow approval of the Global Assessment and adoption of the associated Summary for Policy Makers at IPBES-7. The new assessments are of a different flavour than the previous ones-a "nexus" assessment and one on transformative change.

As we know now that life and the environment are inexorably linked and that people depend on healthy and functioning ecosystems (Lerner and Berg 2017; Schmeller et al. 2018, 2020), the topics of these assessments are a logical next step. The Nexus Assessment will examine the links between food and water security, health, protecting global biodiversity and adapting to climate change through the lens of the sustainable development goals. The Transformative Change Assessment will examine how better conservation, ecosystem restoration and sustainable use of biodiversity may be achieved, considering the totality of the socio-ecological system. In this regard, it is also important to understand and identify factors in human society at both the individual and collective levels (Bridgewater et al. 2019). For example, considering the tragedy of the commons (Kay 1997), the individual self-interest acting against the common good of all, so as to examine all the dimensions that may be leveraged to bring about transformative change in a growing human population. Scoping documents for these two new IPBES assessments were agreed at IPBES8. Following this agreement there will be a call for governments and registered NGOs to 
nominate experts to carry out these assessments, and the full set of experts, timescales, etc., will be settled at IPBES-9, planned in May 2022.

The Nexus and Transformative Change Assessments may well have different modus operandi than previous assessments. As examples, it is foreseen that joint meetings of the management committees of both assessments will take place; that there will be collaboration on internal reviews and between the Technical Support Units (TSUs); and that governments will be invited to review both assessments in parallel. As a result, there was discussion if the two assessments could not be joined completely, a point-of-view supported by several member states. Indeed, given the overlap in content and thus work, it might be more efficient to work on one assessment, rather than two separate ones in parallel. In that regard, one country mentioned policy leakage, referring to the process that sub-global or sub-national policies are often less effective than comprehensive (i.e., global) ones (Streck 2021) and may reduce, for example, the necessary investments in transformative change. Hampering the needed transformative change in favour of business-as-usual will not only lead to an inability to achieve the 2050 vision of biodiversity (Díaz et al. 2020; Mace et al. 2018), but will also interfere with achieving the impact of IPBES. Joining the two assessments may deliver more comprehensive and compelling ways forward from the current impasse faced by human society globally in regard to biodiversity loss and climate change. It may clarify which topics should be prioritized over others from a policy as well as from an ecological/environmental point-of-view. A joint assessment could also lead to strengthening the policy aspects of IPBES (Stevance et al 2020) by better combining policy and ecological/environmental aspects. These points were discussed during a report presented at IPBES-7 (Bridgewater et al. 2019), as IPBES is delivering less strongly on its mandate as a science/knowledge-policy interface (Balvanera et al. 2020).

\section{Deliberation on definitions}

One of the most difficult discussion points in reaching agreement on the scoping documents was around the continuing issue of Indigenous and Local Knowledge (ILK). IPBES has (successfully) tackled the issue of knowledges other than science in seeking ways and means for better stewardship of biodiversity and delivery of ecosystem services. ILK in particular has been the subject of intense discussion by a taskforce from 2013, which developed a set of approaches and procedures for dealing with ILK (Hill et al. 2020). That taskforce continues, but in a supportive role for new assessments. However, some delegations were very strong in requesting ILK and even more complex ways of describing that knowledge in the scoping document. These discussions consumed at least two of the available sessions of the timetable. In the end the issues were resolved. One potential way to ensure this point is not rehearsed again in the future might be to recast the name of the platform to a "Knowledge-Policy Platform", rather than Science-Policy Platform. Science, after all, is but one form of knowledge.

IPBES has certainly made considerable progress in involving ILK in its work, yet much remains to be done. The adoption of Nature's Contributions to People as a title rather than Ecosystem Services also caused considerable discussion. This is certainly an area where much more work outside of IPBES needs to be undertaken to test the validity of new concepts like Natures Contributions to People-recalling the editorial by Leon Braat in the Journal Ecosystem Services where he opined that if the paper announcing NCPs in Science (Díaz et al. 2018) had been submitted to that journal it would have certainly been 
rejected (Braat 2018; see also Kenter 2018). There was also much discussion on whether nature-based solutions $(\mathrm{NbS})$, or ecosystem-based approaches was appropriate terminology for the scoping document. The recent communique from the G7 certainly is sprinkled with references to $\mathrm{NbS}$ (G7 2021), yet the definition and understanding of what such solutions are, and, indeed, what problems they are solving remains elusive. Similarly, there were quite strong views about how far back assessments should take account of environmental changes - some countries suggesting 50 years back is sufficient, other (largely developing) countries making the point that perhaps around the $1500 \mathrm{CE}$ was a better cut-off. This date was also politically loaded as it was the time when significant colonisations on most continents began. It is to be hoped the assessments will help to resolve, or at least clarify, some of these quite critical issues in reaching global solutions to mitigating and adapting to both climate and biodiversity change.

The assessment of both the nexus and transformative change is thus the most significant challenge IPBES faces, as, in contrast to previous assessments, there is not the same breadth and depth of scientific knowledge and literature on the issue available. And how the concepts of nature-based solutions, ecosystem-based approaches, the Ecosystem Approach of the Convention on Biological Diversity, Nature's Contributions to People and Ecosystem Services relate to each other and can translate to effective policy, and ultimately law, is a critical future issue for IPBES.

As we are touching new ground, Biodiversity and Conservation invites manuscripts on topics related to these approaches and with a global view on the transformative change needed by the global human population to achieve the 2050 vision of biodiversity. A special issue on transformative change and closely linked issues, such as prioritization, time frame estimations, connectivity, etc., will therefore directly contribute to the work of IPBES and to enable a nature conservation fit for purpose that allows for co-existence of people and the rest of biodiversity. We therefore invite interested colleagues to contact us for contributions to such a special issue to be published before the next plenary.

The next plenary for IPBES should be held around April-May 2022, probably in Bonn at the seat of Secretariat, and a generous offer was made by the USA to host the 2023 plenary in May, at Madison, Wisconsin.

Acknowledgements D.S.S. holds the AXA Chair for Functional Mountain Ecology funded by the AXA Research Fund through the project GloMEc. P.B. was special adviser to the Australian delegation to IPBES8.

\section{References}

Balvanera P, Jacobs S, Nagendra H, O'Farrell P, Bridgewater P, Crouzat E, Dendoncker N, Goodwin S, Gustafsson KM, Kadykalo AN (2020) The science-policy interface on ecosystems and people: challenges and opportunities. Ecosyst People 16:345-353

Braat LC (2018) Five reasons why the science publication "Assessing nature's contributions to people" (Diaz et al. 2018) would not have been accepted in Ecosystem Services. Ecosyst Serv 30:A1-A2. https://doi.org/10.1016/j.ecoser.2018.02.002

Bridgewater P (2017) The intergovernmental platform for biodiversity and ecosystem services (IPBES) — a role for heritage? Int J Herit Stud 23:65-73. https://doi.org/10.1080/13527258.2016.1232657

Bridgewater P, Loyau A, Schmeller DS (2019) The seventh plenary of the intergovernmental platform for biodiversity and ecosystem services (IPBES-7): a global assessment and a reshaping of IPBES. Biodivers Conserv 28:2457-2461. https://doi.org/10.1007/s10531-019-01804-w

Díaz S, Pascual U, Stenseke M, Martín-López B, Watson RT, Molnár Z, Hill R, Chan KM, Baste IA, Brauman KA (2018) Assessing nature's contributions to people. Science 359:270-272 
Díaz S, Zafra-Calvo N, Purvis A, Verburg PH, Obura D, Leadley P, Chaplin-Kramer R, De Meester L, Dulloo E, Martín-López B, Shaw MR, Visconti P, Broadgate W, Bruford MW, Burgess ND, CavenderBares J, DeClerck F, Fernández-Palacios JM, Garibaldi LA, Hill SLL, Isbell F, Khoury CK, Krug CB, Liu J, Maron M, McGowan PJK, Pereira HM, Reyes-García V, Rocha J, Rondinini C, Shannon L, Shin Y-J, Snelgrove PVR, Spehn EM, Strassburg B, Subramanian SM, Tewksbury JJ, Watson JEM, Zanne AE (2020) Set ambitious goals for biodiversity and sustainability. Science 370:411. https://doi.org/10. $1126 /$ science.abe 1530

G7 (2021) G7 Climate and Environment Ministers' Meeting Communiqué. G7, London. https://assets.publi shing.service.gov.uk/government/uploads/system/uploads/attachment_data/file/988551/g7-climateenvironment-communique.pdf

Hill R, Adem Ç, Alangui WV, Molnár Z, Aumeeruddy-Thomas Y, Bridgewater P, Tengö M, Thaman R, Yao CYA, Berkes F (2020) Working with indigenous, local and scientific knowledge in assessments of nature and nature's linkages with people. Curr Opin Environ Sustain 43:8-20

IPBES (2016) The assessment report of the Intergovernmental Science-Policy Platform on Biodiversity and Ecosystem Services on pollinators, pollination and food production. In: Potts SG, Imperatriz-Fonseca VL, Ngo HT (eds) Secretariat of the Intergovernmental Science-Policy Platform on Biodiversity and Ecosystem Services, Bonn. https://doi.org/10.5281/zenodo.3402856

IPBES (2018) The IPBES regional assessment report on biodiversity and ecosystem services for Africa. In: Archer E, Dziba L, Mulongoy KJ, Maoela MA, Walters M (eds) Secretariat of the Intergovernmental Science-Policy Platform on Biodiversity and Ecosystem Services, Bonn. https://doi.org/10.5281/ zenodo. 3236178

IPBES (2019) Summary for policymakers of the global assessment report on biodiversity and ecosystem services of the Intergovernmental Science-Policy Platform on Biodiversity and Ecosystem Services. IN: Díaz S, Settele J, Brondízio ES, Ngo HT, Guèze M, Agard J, Arneth A, Balvanera P, Brauman PA, Butchart SHM, Chan KMA, Garibaldi LA, Ichii K, Liu J, Subramanian SM, Midgley GF, Miloslavich P, Molnár Z, Obura D, Pfaff A, Polasky S, Purvis A, Razzaque J, Reyers B, Roy Chowdhury R, Shin YJ, Visseren-Hamakers IJ, Willis KJ, Zayas CN (eds) IPBES secretariat, Bonn

Kay CE (1997) The ultimate tragedy of commons. Conserv Biol 11:1447-1448

Kenter JO (2018) IPBES: Don't throw out the baby whilst keeping the bathwater; Put people's values central, not nature's contributions. Ecosyst Serv 33:40-43. https://doi.org/10.1016/j.ecoser.2018.08.002

Lerner H, Berg C (2017) A comparison of three holistic approaches to health: one health, ecohealth, and planetary health. Front Vet Sci 4:163. https://doi.org/10.3389/fvets.2017.00163

Mace GM, Barrett M, Burgess ND, Cornell SE, Freeman R, Grooten M, Purvis A (2018) Aiming higher to bend the curve of biodiversity loss. Nat Sustain 1:448-451

Schmeller DS, Bridgewater P (2016) The Intergovernmental Platform on Biodiversity and Ecosystem Services (IPBES): progress and next steps. Biodivers Conserv 25:801-805. https://doi.org/10.1007/ s10531-016-1095-9

Schmeller DS, Courchamp F, Killeen G (2020) Biodiversity loss, emerging pathogens and human health risks. Biodivers Conserv. https://doi.org/10.1007/s10531-020-02021-6

Schmeller DS, Niemelä J, Bridgewater P (2017) The Intergovernmental Science-Policy Platform on Biodiversity and Ecosystem Services (IPBES): getting involved. Biodivers Conserv 26:2271-2275. https:// doi.org/10.1007/s10531-017-1361-5

Schmeller DS, Loyau A, Bao K, Brack W, Chatzinotas A, De Vleeschouwer F, Friesen J, Gandois L, Hansson SV, Haver M, Le Roux G, Shen J, Teisserenc R, Vredenburg VT (2018) People, pollution and pathogens-global change impacts in mountain freshwater ecosystems. Sci Total Environ 622623:756-763. https://doi.org/10.1016/j.scitotenv.2017.12.006

Stevance A-S, Bridgewater P, Louafi S, King N, Beard TD Jr, Van Jaarsveld AS, Ofir Z, Kohsaka R, Jenderedijan K, Rosales Benites M (2020) The 2019 review of IPBES and future priorities: reaching beyond assessment to enhance policy impact. Ecosyst People 16:70-77

Streck C (2021) REDD+ and leakage: debunking myths and promoting integrated solutions. Clim Policy 21:843-852. https://doi.org/10.1080/14693062.2021.1920363

Publisher's Note Springer Nature remains neutral with regard to jurisdictional claims in published maps and institutional affiliations. 